\title{
THE ESSEX MARSHES
}

\section{Sylvia Townsend Warner}

It was in July 1922, a hot day, I was wearing a cotton dress, and some domestic need took me to Whiteley's cheap section, which was then in the old Westbourne Grove part of the shop, through the golden passage. There was a table which displayed cheap books and stationery, and I always looked at it, though as a rule the cheap books were Reading for Lent, or such-like. This time there were maps. I bought a map of Essex, because $I$ had never been there. It was a Bartholomew map, inch to the mile, coloured for elevation. The blue creeks, the wide expanses of green for marsh, the extraordinary Essex place names - Wick, Old Shrill, High Easter, Willingale Spain and Willingale Doe, High Laver and Little Laver and Shellow Bowells, all delighted me. So on Bank Holiday I went to Fenchurch Street station, and got on a Southend train: meaning, I think, to combine a traditional Bank Holiday custom and a discovery of Essex. I can remember nothing of the journey except my surprise at seeing so many diamonds; almost all the people in my compartment were wearing diamond rings. I can remember nothing of Southend, either, except that I decided to stay in the train till it reached Shoeburyness. At Shoeburyness I found a bus going to Great Wakering. I had not brought my map, but I had read it enough to know that Great Wakering was in a green section with blue creeks. Thence I walked on along a dusty white road with dusty dark elms standing beside it, and turned off along a track into what I knew must be a marsh. So I walked on, and came to a creek, and beyond the creek was a low green shore. I stood there for a long time, watching the slow pushing water, and an 
old white horse grazing on the further shore. I followed the creek, foolishly supposing that there would be some way across. It curled either way, and I began to realise that the low green shore was an island. And this again was marvellous to me, and I stood for another long time, staring, and letting my mind drift with the tidal water.

By this time I was pretty much lost, but I judged by the sun, and began to walk over the mainland marsh. Judging by the sun showed me a very large thundercloud coming from the east. It overhauled me, it covered the sun, the marsh instantly darkened into an alarming flatness. If lightning were to strike the tallest object, then lightning would strike me. The storm broke very suddenly, with a slash of lightning and a spatter of violent rain, and I took to my heels, frightened, like an animal. Then I heard a man's voice calling to me, laughing, rough, and friendly. It came from one of a group of farm-workers, who had taken shelter in a cattle-shed. I sheltered with them, we watched the lightning stabbing at the marsh. It was a considerable storm. In the intervals of the thunder the man who had called me in talked to me, and after the storm had cleared he said I must go with him to his wife, who would dry me.

So I went with him to a small brick cottage, one in a group, and his wife was short and kind with a loud voice, and there was a daughter too, and I think the daughter's young man, and a very loud canary in a cage in the window. The woman took me into a bedroom, and stripped off my drenched clothes, and dressed me in clothes of the daughters, rough home-washed clothes; and while mine were hung to drip in the back-kitchen I had tea with them. The tea was strong, there was a nosegay of violent coloured flowers on the table, the canary sang all the time, there was a great deal to eat, I was very happy. Finally I put on my outer clothes, but retained Maggie's blue woollen bloomers because the woman of the house would not let me, for my health's sake, go home in my own wet cotton drawers. They put me on the road to Gt Wakering, and I went home. I think they were called Judd. The man was a builder's assistant, not a farmworker; he had been patching up the shed when he saw me.

I decided that the next time I went to Essex I would spend a night and see more. This time I went to Southminster, partly 
because it was the last station on a line (as Shoeburyness had been) and also because it was in the middle of a promising bare green section of the map, with a track walk to the name of Stansgate on the Blackwater estuary.

The track walk took me northwards out of Southminster over a low ridge; and into a valley, and up a second ridge; and from the second ridge I looked out over the Blackwater marsh, deeply coloured, dotted with trees, elms in clumps or sprinkled willows. I walked on till the lane ended in a few houses and a sort of small jetty running into the Blackwater. I sat down there, and stared about me, and saw with rapture the sail of a boat moving behind some trees, and seeming to move across the land. After some time I began to look about for an inn, and then to enquire for it. There was no inn. Consulting my map, I saw there was no inn on the map, either. I had been divinely misled.

I was resolved not to go back. If need be, I would sleep out. But a boy who had been looking at me now came nearer, and agreed with me that there was no inn; and then added that perhaps Mrs May would let me stay for the night. Mrs May, he said, at Drinkwaters. I had passed Drinkwaters, he said, half a mile back along the road, it stood off to the right. About six in the evening I walked back, careless from contentment, and saw the track running straight across two small meadows to a small straight up and down brick house with some farmbuildings beside it. There was a tall thin woman moving about among rows of scarlet runners, I went up to her, and asked if she were Mrs May, and if she could give me a bed for a night. She looked me up and down, carefully, but without haste or fluster, and said I might stay, adding that as it happened her sister who had been staying with her had gone that same day, and that she had not put the room back yet.

She spoke kindly, yet I am sure she did not take me in from kindness only. It was partly interest, and partly liking. We liked at first sight: it is quite as definite a process as love at first sight. She showed me the bedroom. It was small, with a double bed, and a large washstand with a very large white basin and ewer and chamberpot; large and round as moons. The floor was covered with deliciously cold smooth oil-cloth. It was clean, solemn, and unusually austere for a cottage room. 
There was a sitting-room downstairs, into which I was put for my supper. It had darkish green walls, and a large centre table, and more delicious oil-cloth, and solid dark mahogany furniture. My supper was bread and cheese, and some of the runner beans she had been picking, and a choice of tea or herbbeer. I chose the herb-beer. Mrs May had made it. It was served in a heavy cut-glass tumbler, and tasted of no particular herb, but was solid, and cool, and extremely refreshing, and seemed of a piece with the darkish green walls and dark mahogany furniture. After supper I sat on alone in a sort of solemn rapture till Mrs May asked me if I would like the lamp, and I said I would prefer to go to bed.

When I woke in the morning and remembered that I had spent the night in the middle of an Essex marsh I jumped out of bed to look out of the window. I could see nothing but an intense blue sky, and a thick white mist, a mushroom mist, from which the thatched roof of the barn and some low tree-tops emerged. This melting veil over my new landscape pleased me more than any clear sight could do. I watched it thin, and become stained with the appearance of a barn, and some sheds, and the beanvines in the garden, and some apple trees, and the green of the marsh beyond. Going downstairs I found Mrs May, and at once asked her if I could spend another night at Drinkwaters.

A whole day in the marsh, and another evening in the greenwalled room and another night in the dusky bedroom with the moony glimmer of the wash-stand china was before me. I took my map, and set out northward for the estuary. I took my book, too, an Inselverlag Pandora edition of Villon's Testament, also bought at Whiteley's cheap counter; and coming to the Blackwater I sat down in a nest of tall grass, and began to read.

The nest of tall grass gave onto a little bank of shingle, the ripples clinked over it, the sun shone. I knew that mysterious sensation of being where I wanted to be and as I wanted to be, socketted in the universe, and passionately quiescent. But beyond any other sense, my sense of smell substantiated my pleasure. Refreshed all night by the mist, and now penetrated by the warmth of the sun, the marsh was exhaling its particular smell, pure, fertile, sweet with vegetation, and yet slightly salt; a smell ....[and here the $M S$ ends abruptly, the remainder presumably lost $-e d]$ 